\title{
Antifungal, cytotoxic activities and docking studies of 2,5-dimercapto-1,3,4-thiadiazole derivatives
}

\author{
Weerasak Samee $^{1 \star}$ and Opa Vajragupta ${ }^{2}$ \\ ${ }^{1}$ Department of Pharmaceutical Chemistry and Pharmacognosy, Faculty of Pharmacy, Srinakharinwirot University, \\ Nakhon-nayok, Thailand. \\ ${ }^{2}$ Department of Pharmaceutical Chemistry, Faculty of Pharmacy, Mahidol University, Bangkok, Thailand.
}

Accepted 30 March, 2011

\begin{abstract}
A series of 2,5-dimercapto-1,3,4-thiadiazole derivatives (compounds 1 to 10) were prepared by nucleophilic substitution reaction between 2,5-dimercapto-1,3,4-thiadiazole and chloroheterocyclic compounds in methanol and in the presence of potassium carbonate (compounds 1 to 5 and 8 ) or metallic sodium (compounds $6,7,9$ and 10) at room temperature. The cytotoxic activity was determined by green fluorescent protein (GFP)-based assay and anti-candida activity was determined by resazurin microplate assay (REMA). Compounds 1 to 4,8 and 9 showed in vitro cytotoxic activities against Vero cells (African green monkey kidney). Compounds 4 and 10 exhibited anti-candida activities against Candida albicans (ATCC 90028) with IC $_{50}$ values of 1.94 and $19.10 \mu \mathrm{g} / \mathrm{ml}$, respectively. Docking studies on the catalytic site of cytochrome P450 14 $\alpha$-demethylase were used to identify the chemical structures in the molecule responsible for cytotoxic and anti-candida activities of the synthesized compounds.
\end{abstract}

Key words: 2,5-dimercapto-1,3,4-thiadiazol, docking, cytotoxicity, antifungal.

\section{INTRODUCTION}

The incidence of primary and opportunistic fungal infections continues to increase rapidly because of the increased number of immunocompromised patients (AIDS, cancer and transplants) (Dismukes, 2000; Singh, 1997). Candida sp. is one of the most well-known fungal pathogens which accounts for majority of opportunistic fungal infections occurring worldwide (Odds, 1996). The class of azoles (imidazole and triazole derivatives) has supplied many effective antifungal drugs currently in clinical use (Andriole, 2000; De Pauw and Picazo, 2008; Katritzky et al., 2008; Sheehan et al., 1999). Resistance to wide spectrum antifungal agents has initiated the search for new therapeutic agents, including those produced by the modification of existing antifungal drugs (Joseph-Horne and Hollomon, 1997; Dupont et al., 1996; Cartledge et al., 1997). The azole ring has been demonstrated to be one of the most important pharmacophores for antifungal activity, and both the

${ }^{\star}$ Corresponding author. E-mail: weerasak@swu.ac.th. Tel: 6626495043. Fax: 663-7395096. toxicity and activity of azole antifungal agents are mainly attributed to coordination binding of the nitrogen atom of the azole ring to the iron atom of heme (Zhu et al., 2006). These facts led us to search for novel azole lead compounds with more structural specificity for fungal enzymes in order to separate their activity from their toxicity.

The synthesis of compounds containing 1,3,4thiadiazoles has attracted widespread attention due to their diverse applications as antifungals (Jalilian et al., 2003; Liu et al., 2009), anticancer agents (Wei et al., 2009; Ibrahim, 2009; Zheng et al., 2008; Matysiak and Opolski, 2006), antibacterial agents (Demirbas et al., 2009; Padmavathi et al., 2009; Pintilie et al., 2007), antiinflammatory drugs (Jadhav et al., 2008; Rostom et al., 2009), antidepressants (Yusuf et al., 2008; Jatav et al., 2008), carbonic anhydrase inhibitors (Kasımoğulları et al., 2009; Abdel-Hamid et al., 2007), anti-Helicobacter pylori agents (Mirzaei et al., 2008), antitrypanosomals (Carvalho et al., 2004) and leishmanicidal agents (Foroumadi et al., 2005). In the present study we report the synthesis of novel 2,5-dimercapto-1,3,4-thiadiazole derivatives with alkyl heterocyclic or heterocyclic 
moieties. A major aim of this study was to study the anticandida and cytotoxic activities of these derivatives. We also performed molecular docking studies using the AutoDock v3.0 program with the aim of explaining the mode of action of 2,5-dimercapto-1,3,4-thiadiazole derivatives with the active site of $14 \alpha$-demethylase enzyme.

\section{MATERIALS AND METHODS}

A series of 2,5-dimercapto-1,3,4-thiadiazole derivatives (compounds 1 to 10) were prepared by nucleophilic substitution reaction between 2,5-dimercapto-1,3,4-thiadiazole and chloroheterocyclic compounds in methanol and in the presence of potassium carbonate (compounds 1 to 5 and 8 ) or sodium metal (compounds $6,7,9$ and 10) in room temperature. The crude product was purified by crystallization from methanol. The melting point of all compounds was determined using an Electrothermal IA9200 melting point apparatus. Infrared spectra were run on a Perkin Elmer Spectrum One FTIR spectrophotometer, using the potassium bromide pellet technique. ${ }^{1}$ HNMR spectra were obtained on an INOVA-500 (500 $\mathrm{MHz}$ ) NMR spectrometer. Chemical shifts were reported in ppm related to the internal standard, tetramethylsilane (TMS). The NMR solvent used was deuterated dimethyl sulfoxide (DMSO, $\delta=2.54$ ppm). Mass spectra were determined on a MAT 90 (Finnigan) mass spectrometer using El method. The percentages of carbon, hydrogen and nitrogen were obtained using a $\mathrm{CHNS} / \mathrm{O}$ analyzer (Perkin Elmer PE2400 series II). Chemical reagents were obtained from Aldrich and Fluka Company.

\section{General method for the synthesis of compounds 1 to 5 and 8 .}

$690 \mathrm{mg}(5 \mathrm{mmol})$ of $\mathrm{K}_{2} \mathrm{CO}_{3}$ was dissolved in $30 \mathrm{ml}$ of absolute methanol and then mixed with $5 \mathrm{mmol}$ of 2,5-dimercapto-1,3,4thiadiazole. To this mixture was added $5 \mathrm{mmol}$ of chloroalkyl heterocyclic compound or chloro heterocyclic compound. The reaction solution was stirred at room temperature for $3 \mathrm{~h}$. The pale yellow precipitate was collected by filtration and the precipitate was purified by recrytallization with $\mathrm{MeOH}$.

5-(6-chloropyridazin-3-ylthio)-1,3,4-thiadiazole-2-thiol (1): Yield 62.50\%; m.p. $216-217^{\circ} \mathrm{C}$; ${ }^{1} \mathrm{HNMR} 500 \mathrm{MHz}$ (DMSO): $\delta 7.98$ (d, $J=$ $\left.9.25 \mathrm{~Hz}, 1 \mathrm{H} \mathrm{H}^{\prime}\right), 8.12\left(\mathrm{~d}, J=9.25 \mathrm{~Hz}, 1 \mathrm{H} \mathrm{H} 4^{\prime}\right)$; FTIR $(\mathrm{KBr})\left(\mathrm{cm}^{-1}\right)$ : 3042 (aromatic C-H st.), 2515 (S-H st.), 1601 (C=C st.), 724 (C-S st.); EIMS: $\mathrm{m} / \mathrm{z}$ (relative intensity) $\mathrm{M}^{+}+2$ 264(32.5), $\mathrm{M}^{+}$262(100.0), 149(48.7), 113(36.3); Anal.Calcd for $\mathrm{C}_{6} \mathrm{H}_{3} \mathrm{CIN}_{4} \mathrm{~S}_{3}$ (262.76): C, 27.43; $\mathrm{H}, 1.15 ; \mathrm{N}, 21.32$. Found: C, 27.45; H, 1.17, N, 21.28.

5-(6-chloroquinolin-4-ylthio)-1,3,4-thiadiazole-2-thiol (2): Yield 77.50\%; m.p. $175-176{ }^{\circ} \mathrm{C}$; ${ }^{1} \mathrm{HNMR} 500 \mathrm{MHz}$ (DMSO): $\delta 8.92$ (d, $J=$ $\left.4.75 \mathrm{~Hz}, 1 \mathrm{H} \mathrm{H} 8^{\prime}\right), 8.24$ (d, $\left.J=9.50 \mathrm{~Hz}, 1 \mathrm{H} \mathrm{H} 5^{\prime}\right), 8.19$ (d, $J=2.25$ $\left.\mathrm{Hz}, 1 \mathrm{H} \mathrm{H} 2^{\prime}\right), 7.80$ (dd, $J=9.50,2.25 \mathrm{~Hz}, 1 \mathrm{H} \mathrm{H} 4$ '), 7.78 (d, $J=4.75$ $\left.\mathrm{Hz}, 1 \mathrm{H} \mathrm{H} 7^{\prime}\right)$; FTIR $(\mathrm{KBr})\left(\mathrm{cm}^{-1}\right)$ : 3083 (aromatic C-H st.), 2537 (S-H st.), 1601 (C=C st.), 716 (C-S st.); EIMS: m/z (relative intensity) $\mathrm{M}^{+}$ +2 313(36.2), $\mathrm{M}^{+}$311(100.0), 162(37.9), 149(50.2); Anal.Calcd for $\mathrm{C}_{11} \mathrm{H}_{6} \mathrm{CIN}_{3} \mathrm{~S}_{3}$ (311.83): C, 42.37; $\mathrm{H}, 1.94 ; \mathrm{N}, 13.48$. Found: $\mathrm{C}, 42.18$; $\mathrm{H}, 1.89 ; \mathrm{N}, 13.55$.

5-((6-chloro-2-(methylthio)pyrimidin-4-ylthio)-1,3,4-thiadiazole2-thiol (3): Yield 67.20\%; m.p. 176-177 ${ }^{\circ} \mathrm{C}$; ${ }^{1} \mathrm{HNMR} 500 \mathrm{MHz}$ (DMSO): $\delta 7.68$ (s, $\left.1 \mathrm{H} \mathrm{H} 5^{\prime}\right), 2.45\left(\mathrm{~s}, 3 \mathrm{H} \mathrm{SCH}_{3}\right) ; \mathrm{FTIR}(\mathrm{KBr})\left(\mathrm{cm}^{-1}\right)$ : 3060 (aromatic C-H st.), 2948 (aliphatic C-H st.), 2520 (S-H st.), 1601 (C=C st.), 725 (C-S st.); EIMS: m/z (relative intensity) $\mathrm{M}^{+}+2$ 310(32.8), $\quad \mathrm{M}^{+}$308(100.0), 293(49.6), 159(35.2), 149(45.1);
Anal.Calcd for $\mathrm{C}_{7} \mathrm{H}_{5} \mathrm{CIN}_{4} \mathrm{~S}_{4}$ (308.85): C, 27.22; $\mathrm{H}, 1.63 ; \mathrm{N}, 18.14$. Found: C, 27.21; $\mathrm{H}, 1.60, \mathrm{~N}, 18.18$.

5-(3-(4-(3-chlorophenyl)piperazin-1-yl)propylthio)-1,3,4

thiadiazole-2-thiol (4): Yield 58.48\%; m.p. $209-210{ }^{\circ} \mathrm{C}$; ${ }^{1} \mathrm{HNMR}$ $500 \mathrm{MHz}$ (DMSO): $\delta 7.25$ (t, $\left.J=8.00 \mathrm{~Hz}, 1 \mathrm{H} \mathrm{H} 5^{\prime \prime}\right), 7.04$ (d, $J=2.25$ Hz, $1 \mathrm{H} \mathrm{H} 2$ "), 6.95 (dd, $J=8.00,2.25 \mathrm{~Hz}, 1 \mathrm{H} \mathrm{H} 4$ "), 6.86 (d, $J=8.00$ $\left.\mathrm{Hz}, 1 \mathrm{H} \mathrm{H6} 6^{\prime \prime}\right), 3.74$ (t, $\left.J=6.00 \mathrm{~Hz}, 2 \mathrm{H} \mathrm{H} 1^{\prime}\right) 3.23(\mathrm{~m}, 4 \mathrm{H}$ H2', H3", H5", H6"'), 2.78 (t, J = $6.00 \mathrm{~Hz}, 2 \mathrm{H} \mathrm{H3}$ '), 2.18 (m, 2H H2'); FTIR $(\mathrm{KBr})\left(\mathrm{cm}^{-1}\right)$ : 3050 (aromatic C-H st.), 2952 (aliphatic C-H st.), 2472 (S-H st.), 1595 (C=C st.), 1252 (C-N st.), 714 (C-S st.); EIMS: $\mathrm{m} / \mathrm{z}$ (relative intensity) $\mathrm{M}^{+}+2$ 388(34.5), $\mathrm{M}^{+}$386(100.0), 237(34.7), 149(48.1), 127(25.5), 111(33.5); Anal.Calcd for $\mathrm{C}_{15} \mathrm{H}_{19} \mathrm{ClN}_{4} \mathrm{~S}_{3}$ (386.99): C, 46.55; H, 4.95; N, 14.48. Found: C, 46.48; H, 4.99; N, 14.52 .

2((5-mercapto-1,3,4-thiadiazol-2-ylthio)methyl)isoindoline-1,3dione (5): Yield 58.48\%; m.p. 161-162 ${ }^{\circ} \mathrm{C}$; ${ }^{1} \mathrm{HNMR} 500 \mathrm{MHz}$ (DMSO): $\delta 7.89$ (m, 4H H4',H5'H6',H7'), 5.31 (s, 2H SCH ${ }_{2} \mathrm{~N}$ ); FTIR $(\mathrm{KBr})\left(\mathrm{cm}^{-1}\right): 3101$ (aromatic C-H st.), 2951 (aliphatic C-H st.), 2562 (S-H st.), 1713 (C=O st.), 1610 (C=C st.), 1210 (C-N st.), 727 (C-S st.); EIMS: $\mathrm{m} / \mathrm{z}$ (relative intensity) $\mathrm{M}^{+}$309(100.0), 161(40.5), 146(48.8), 163(30.5), 149(41.5); Anal.Calcd for $\mathrm{C}_{11} \mathrm{H}_{7} \mathrm{~N}_{3} \mathrm{O}_{2} \mathrm{~S}_{3}$ (309.39): C, 42.70; H, 2.28; N, 13.58. Found: C, 42.65; H, 2.32; N, 13.61 .

5-(6-methoxypyridazin-3-ylthio)-1,3,4-thiadiazol-2-thiol (8): Yield 64.32\%; m.p. $162-163{ }^{\circ} \mathrm{C}$; ${ }^{1} \mathrm{HNMR} 500 \mathrm{MHz}$ (DMSO): $\delta 7.90$ (d, $J=$ $9.25 \mathrm{~Hz}, 1 \mathrm{H} \mathrm{H} 4^{\prime}$ ), 7.33 (d, $J=9.25 \mathrm{~Hz}, 1 \mathrm{H} \mathrm{H}^{\prime}$ ), 4.03(s, $3 \mathrm{H} \mathrm{OCH}_{3}$ ); FTIR $(\mathrm{KBr})\left(\mathrm{cm}^{-1}\right): 3070$ (aromatic C-H st.), 2952 (aliphatic C-H st.), 2550 (S-H st.), 1068 (C-O st.), 726 (C-S st.); EIMS: m/z (relative intensity) $\mathrm{M}^{+}$258(100.0), 243(49.4), 149(44.1), 109(33.5); Anal.Calcd for $\mathrm{C}_{7} \mathrm{H}_{6} \mathrm{~N}_{4} \mathrm{OS}_{3}$ (258.34): C, 32.54; $\mathrm{H}, 2.34 ; \mathrm{N}, 21.69$. Found: C, 32.59; $\mathrm{H}, 2.37$; N, 21.60.

\section{General method for the synthesis of compounds $6,7,9$ and 10}

$115 \mathrm{mg}(5 \mathrm{mmol})$ of metallic sodium was dissolved in $30 \mathrm{ml}$ of absolute methanol and then mixed with $5 \mathrm{mmol}$ of 2,5-dimercapto1,3,4-thiadiazole. To this mixture was added $5 \mathrm{mmol}$ of chloroalkyl heterocyclic compound or chloro heterocyclic compound. The reaction solution was stirred at room temperature for $3 \mathrm{~h}$, and then concentrated under reduced pressure to remove the methanol. 40 $\mathrm{ml}$ of ethyl acetate and $20 \mathrm{ml}$ of water were added to the residue, with vigorous stirring. The organic phase was separated, washed twice with water, dried over anhydrous sodium sulfate and concentrated in vacuo. Ethyl acetate was removed by rotary evaporator. Purification of the crude residue by recrystallization $(\mathrm{MeOH})$ gave a solid product.

6-(5-mercapto-1,3,4-thiadiazol-2-ylthio)-4H-chromen-4-one (6): Yield 48.26\%; m.p. 228-229 ${ }^{\circ} \mathrm{C}$; ${ }^{1} \mathrm{HNMR} 500 \mathrm{MHz}$ (DMSO): $\delta 9.07$ (s, 1H SH), 8.04 (d, $J=2.75 \mathrm{~Hz}, 1 \mathrm{H} \mathrm{H5}$ ), 7.95 (dd, $J=8.75,2.75$ Hz, $1 \mathrm{H} \mathrm{H}^{\prime}$ ), 7.94(d, $J=8.75,1 \mathrm{H} \mathrm{H}^{\prime}$ ), 7.84 (d, $J=8.75$ Hz, 2H H8', $\left.\mathrm{H}^{\prime}\right)$; FTIR $(\mathrm{KBr})\left(\mathrm{cm}^{-1}\right)$ : 3150 (aromatic C-H st.), 2568 (S-H st.), 1639 (C=O st.), 1606 (C=C st.), 1254 (C-O st.), 717 (C-S st.); EIMS: $\mathrm{m} / \mathrm{z}$ (relative intensity) $\mathrm{M}^{+}$294(100.0), 149(41.5), 145(34.8); Anal.Calcd for $\mathrm{C}_{11} \mathrm{H}_{6} \mathrm{~N}_{2} \mathrm{O}_{2} \mathrm{~S}_{3}$ (294.37): C, 44.88; $\mathrm{H}, 2.05 ; \mathrm{N}, 9.52$. Found: C, 44.75; H, 2.09; N, 9.58.

3-((5-mercapto-1,3,4-thiadiazol-2-ylthio)methyl)quinolin2,4(1H,4H)-dione (7): Yield 55.91\%; m.p. $252-253{ }^{\circ} \mathrm{C} ;{ }^{1} \mathrm{HNMR} 500$ MHz (DMSO): $\delta 11.47$ (s, $1 \mathrm{H} \mathrm{SH}$ ), 7.91 (dd, $J=8.00,1.00 \mathrm{~Hz}, 1 \mathrm{H}$ H5'), 7.65 (td, $J=8.00,1.50$ Hz, $1 \mathrm{H} \mathrm{H6}^{\prime}$ ), 7.19(m, 2H H7',H8'), 4.22 (t, $\left.J=5.75 \mathrm{~Hz}, 1 \mathrm{H} \mathrm{H} 3^{\prime}\right), 3.55(\mathrm{~d}, J=5.75 \mathrm{~Hz}, 2 \mathrm{H} \mathrm{CH}$ ); FTIR $(\mathrm{KBr})\left(\mathrm{cm}^{-1}\right): 3436(\mathrm{~N}-\mathrm{H}$ st.), 3096 (aromatic $\mathrm{C}-\mathrm{H}$ st.), 2998 (aliphatic 
C-H st.), 2570 (S-H st.), 1713 (C=O st.), 1649 (N-C=O st.), 1604 (C=C st.), 1291 (C-N st.), 714 (C-S st.); EIMS: m/z (relative intensity) $\mathrm{M}^{+}$323(100.0), 174(66.4), 149(40.2); Anal.Calcd for $\mathrm{C}_{12} \mathrm{H}_{9} \mathrm{~N}_{3} \mathrm{O}_{2} \mathrm{~S}_{3}$ (323.41): C, 44.56; $\mathrm{H}, 2.80 ; \mathrm{N}, 12.99$. Found: $\mathrm{C}$, 44.50; H, 2.79; N, 12.86 .

5-(2-methylbenzo[d]thiazol-5-ylthio)-1,3,4-thiadiazol-2-thiol (9): Yield 35.28\%; m.p. 211-212 ${ }^{\circ} \mathrm{C}$; ${ }^{1} \mathrm{HNMR} 500 \mathrm{MHz}$ (DMSO): $\delta 7.77$ (d, $J=3.00 \mathrm{~Hz}, 1 \mathrm{H} \mathrm{H} 4^{\prime}$ ), 7.76 (d, $J=6.25 \mathrm{~Hz}, 1 \mathrm{H} \mathrm{H} 7^{\prime}$ ), 7.50(dd, $J=$ 6.25, $3.00 \mathrm{~Hz}, 1 \mathrm{H} \mathrm{H}^{\prime}$ ), 4.90 (s, 3H CH $\mathrm{CH}_{3}$; FTIR $(\mathrm{KBr})\left(\mathrm{cm}^{-1}\right): 3013$ (aromatic C-H st.), 2958 (aliphatic C-H st.), $1376\left(\mathrm{CH}_{3}\right.$ bending), 715 (C-S st.); EIMS: $\mathrm{m} / \mathrm{z}$ (relative intensity) $\mathrm{M}^{+}$297(100.0), 149(40.2), 148(54.3); Anal.Calcd for $\mathrm{C}_{10} \mathrm{H}_{6} \mathrm{~N}_{3} \mathrm{~S}_{4}$ (297.44): C, 40.38; $H, 2.37$; N, 14.13. Found: C, 40.31; H, 2.40; N, 14.09.

1-(2-(5-mercapto-1,3,4-thiadiazol-2-thio)phenyl)-3-methyl-1Hpyrazol-5(4H)-one (10): Yield 26.45\%; m.p. $162-163{ }^{\circ} \mathrm{C}$; ${ }^{1} \mathrm{HNMR}$ $500 \mathrm{MHz}$ (DMSO): $\delta 7.75$ (d, $\left.J=9.00 \mathrm{~Hz}, 1 \mathrm{H} \mathrm{H} 6^{\prime \prime}\right), 7.67$ (d, $J=9.00$ $\mathrm{Hz}, 1 \mathrm{H} \mathrm{H} 2$ "), 7.53 (d, $J=9.00 \mathrm{~Hz}, 1 \mathrm{H} \mathrm{H} 3$ "), 7.48 (d, $J=9.00 \mathrm{~Hz}, 1 \mathrm{H}$ H3"), 2.15 (s, 2H H4'”) 2.00 (s, 3H CH $\mathrm{H}_{3}$ ); FTIR (KBr) $\left(\mathrm{cm}^{-1}\right): 3050$ (aromatic C-H st.), 2950 (aliphatic C-H st.), 2555 (S-H st.), 1622 (N$\mathrm{C}=\mathrm{O}$ st.), 1591 ( $\mathrm{C}=\mathrm{C}$ st.), 1363 ( $\mathrm{CH}_{3}$ bending), 741 (C-S st.); EIMS: $\mathrm{m} / \mathrm{z}$ (relative intensity) $\mathrm{M}^{+}$322(100.0), 225(30.5), 173(48.9), 149(55.6), 97(31.7); Anal.Calcd for $\mathrm{C}_{12} \mathrm{H}_{10} \mathrm{~N}_{4} \mathrm{OS}_{3}$ (322.43): C, 44.70; H, 3.13; N, 17.38. Found: C, 44.78; H, 3.19; N, 17.32 .

\section{Cytotoxicity assay (Hunt et al., 1999)}

The GFP-expressing Vero cell line was generated in-house by stably transfecting the African green monkey kidney cell line (Vero, ATCC CCL-81), with pEGFP-N1 plasmid (Clontech). The cell line was maintained in a minimal essential medium supplemented with $10 \%$ heat-inactivated fetal bovine serum, $2 \mathrm{mM}$ L-glutamine, $1 \mathrm{mM}$ sodium pyruvate, $1.5 \mathrm{~g} / \mathrm{L}$ sodium bicarbonate and $0.8 \mathrm{mg} / \mathrm{ml}$ geneticin, at $37^{\circ} \mathrm{C}$ in a humidified incubator with $5 \% \mathrm{CO}_{2}$. The assay was carried out by adding $45 \mu \mathrm{l}$ of cell suspension with $3.3 \mathrm{x}$ $10^{4} \mathrm{cells} / \mathrm{ml}$ to each well of 384 well plates containing $5 \mu \mathrm{l}$ of test compounds previously diluted in $0.5 \%$ DMSO, and then incubated for 4 days at $37^{\circ} \mathrm{C}$ in an incubator with $5 \% \mathrm{CO}_{2}$. Fluorescence signals were measured using a SpectraMax M5 microplate reader (Molecular Devices, USA) in the bottom reading mode with excitation and emission wavelengths of 485 and $535 \mathrm{~nm}$. The background fluorescence at day zero was subtracted from the fluorescence signal at day 4 . The percentage of inhibition was calculated using the following equation, where FUT and FUC represent the fluorescence units of cells treated with the test compound and the untreated cells, respectively:

$\%$ inhibition $=[1-($ FUT $/$ FUC $)] \times 100$

The compounds were considered cytotoxicity when percentage inhibition was $50 \%$ or greater at the concentration of $50 \mu \mathrm{g} / \mathrm{ml}$. The $\mathrm{IC}_{50}$ values are derived from dose-response curves, using 6 concentrations of 2 fold serially diluted samples, using SOFTMax Pro software (Molecular device). Ellipticine and 0.5\% DMSO were used as positive and negative controls, respectively.

\section{Antifungal activity assay (Brien et al., 2000)}

Candida albicans (ATCC 90028) was grown on a potato dextrose agar (PDA) plate at $30^{\circ} \mathrm{C}$ for 3 days. Three to five single colonies were then cultured in a shaking flask containing RPMI-1640 until cell density reached $5 \times 10^{5} \mathrm{CFU} / \mathrm{ml}$. The yeast cell suspension was added to a 384 well plate; each well containing $45 \mu \mathrm{l}$ of cell suspension and $5 \mu \mathrm{l}$ of test sample. The plates were then incubated at $37^{\circ} \mathrm{C}$ for $4 \mathrm{~h}$. Thereafter, $10 \mu \mathrm{l}$ of $62.5 \mu \mathrm{g} / \mathrm{ml}$ resazurin solutions was added to each well and incubated at $37^{\circ} \mathrm{C}$ for $30 \mathrm{~min}$. Fluorescent intensity was measured at the excitation wavelength of $530 \mathrm{~nm}$ and the emission wavelength of $590 \mathrm{~nm}$ using the SpectraMax M5 microplate reader (Molecular Devices, USA). The fluorescence signal from wells containing only medium was used for background subtraction. The percentage of inhibition was determined from the units of fluorescence of treated cells (FUT) and untreated cells (FUC) using the following equation:

$\%$ Inhibition $=[1-($ FUT $/$ FUC $)] \times 100$

The $50 \%$ inhibitory concentration $\left(\mathrm{IC}_{50}\right)$ was determined from the dose response curve, using 6 concentrations of 2 fold serial dilutions. Amphotericin B and $0.5 \%$ DMSO were used as a positive and a negative controls, respectively.

\section{Molecular docking studies}

The X-ray crystal structure of sterol 14alpha-demethylase (CYP51) binding sites complexed with inhibitor, (2S)-2-[(2,1,3-benzothiazol4-ylsulfonyl) aminothiadiazol-4-ylsulfonyl)amino]-2-phenyl-N-pyridin4-ylacetamide (2CIB) was obtained from the RSCB Protein Data Bank (RSCB PDB) (Podust et al., 2007). The docking procedure was performed with version 3.0 of AutoDock program. It combines a rapid energy evaluation through pre-calculated grids of affinity potentials with a variety of search algorithms to find suitable binding positions for a ligand on a given protein. In AutoDock, the protein is required to be rigid, but the program allows torsion in the ligand. A docking study of compounds with CYP51 was carried out using the Lamarckian genetic algorithm, applying a standard protocol, with an initial population of 100 randomly placed individuals, a maximum number of $1.5 / 10^{6}$ energy evaluations, a mutation rate of 0.02 , a cross over rate of 0.80 , and an elitism value of 1 . One hundred independent docking runs were carried out for each ligand. Results differing by less than $2.0 \AA \AA$ in positional root mean-square deviation (rmsd) were clustered together and represented the result with the most favorable free energy of binding.

The structures of the ligand were generated with SYBYL 7.0. Atomic charges were assigned using the Gasteiger-Marsili formalism, which is the type of atomic charge used in calibrating the Autodock empirical free energy function. Finally the compounds were set up for docking with the help of AutoTors utility, the main purpose of which is to define the torsional degrees of freedom to be considered during the docking process.

The structure of the CYP51 catalytic core domain (PDB 2CIB) was setup as follows: polar hydrogens were added using the PROTONATE utility; Kollman charge and salvation parameters were added to the final protein file using the ADDSOL utility of AutoDock 3.0. The grid maps representing the protein in the actual docking process were calculated with AutoGrid. The grids (one for each atom type in the ligand, plus one for electrostatic interactions) were chosen to be sufficiently large to include not only the active site but also significant portions of the surrounding surface. The dimensions of the grids were thus $60 \AA$ × $\times 60 \AA$ × $60 \AA$, with $a$ spacing of $0.375 \AA$ between the grid points and the center placed at the mid point between His259 and Tyr76.

\section{RESULTS AND DISCUSSION}

\section{Chemistry}

Monosubstituted 2,5-dimercapto-1,3,4-thiadiazole derivatives were prepared by nucleophilic substitution of 2,5-dimercapto-1,3,4-thiadiazole with the proper chloro 


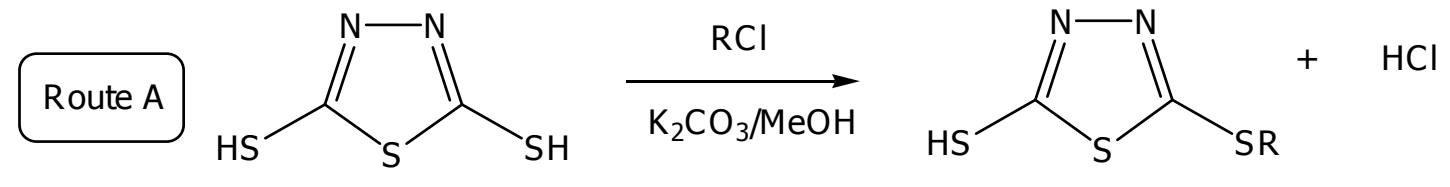

$1-5,8$

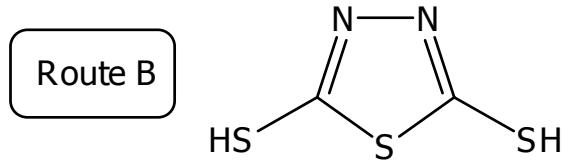

Cpd. R

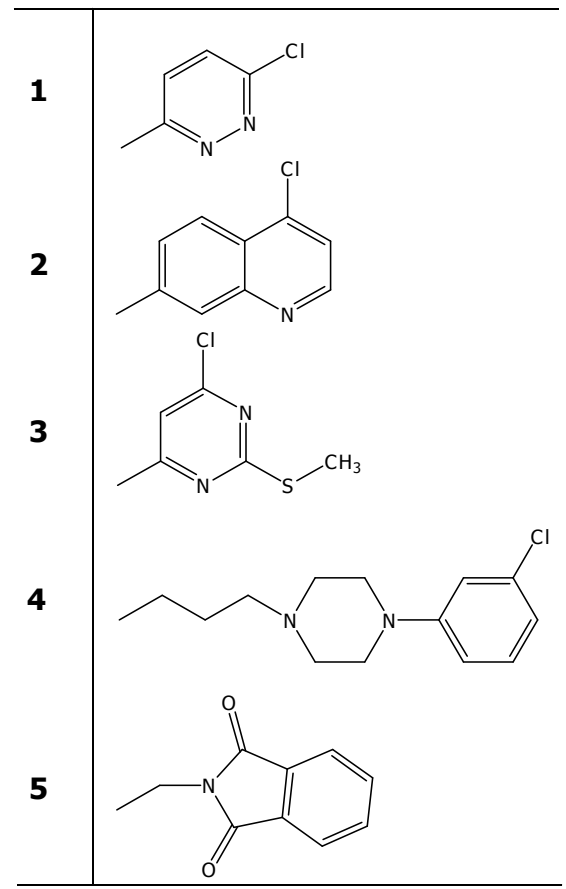

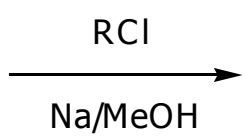<smiles>[R5]c1nnc(S)s1</smiles>

$6,7,9,10$

Cpd. R

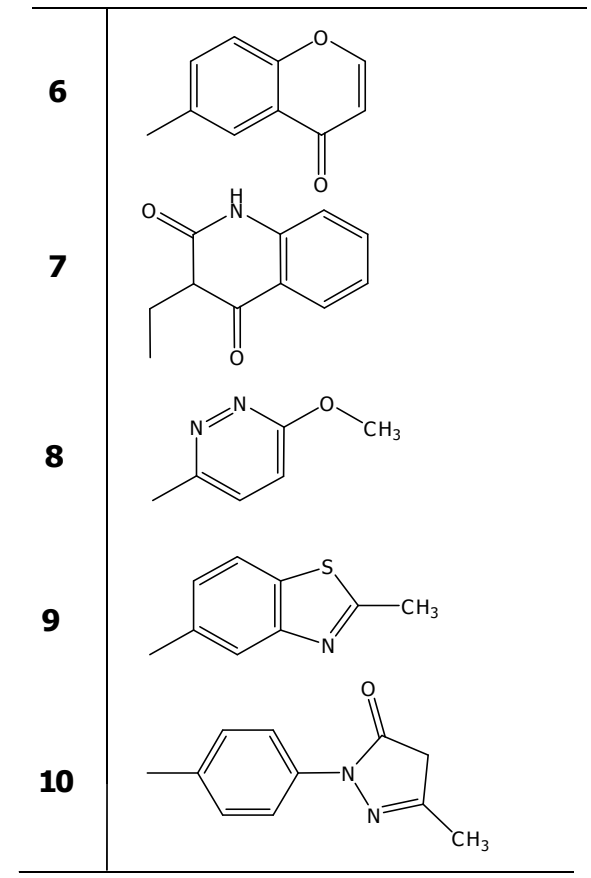

Scheme 1. Synthesis of 2,5-dimercapto-1,3,4-thiadiazole derivatives.

heterocyclic compounds, using two alternate routes depending on the electrophiles at room temperature: $(A)$ methanol in the presence of potassium carbonate; and (B) methanol in the presence of metallic sodium (Scheme 1).

The IR spectra of all compounds showed weak absorption bands within the $2470-2570 \mathrm{~cm}^{-1}$ range which were attributed to $\mathrm{SH}$ function vibration. The absorption band of the -C-S function appears in the $714-741 \mathrm{~cm}^{-1}$ region. In the ${ }^{1} \mathrm{H}$-NMR spectra, the proton signals due to the $\mathrm{SH}$ group were recorded between 9.07 and 11.47 ppm. Mass spectra of all compounds showed molecular ion $\left(\mathrm{M}^{+}\right)$peaks and 2,5-dimercapto-1,3,4-thiadiazole fragment $\left(\mathrm{C}_{2} \mathrm{H}_{2} \mathrm{~N}_{2} \mathrm{~S}_{3}{ }^{+}\right)$at $\mathrm{m} / \mathrm{z}=149$. The elemental analysis results were all in good agreement with the structure proposed for all compounds.

\section{Pharmacology}

All compounds were evaluated in vitro for antifungal activity against pathogenic fungi ( $C$. albicans). Amphotericin B was used as the reference drug. As shown in Table 1, substitution of 1-(3-chlorophenyl)-4-(3propyl)piperazine moiety (compound 4) and 1-phenyl-3methyl-2-pyrazolin-5-one (compound 10) exhibited an anti-candida activity with the $\mathrm{IC}_{50}$ values of 1.94 and $19.10 \mu \mathrm{g} / \mathrm{ml}$, respectively. These results suggested that the appropriate substitution of a long chain moiety (compound 4 and 10) was important for anti-candida activities. Compound 1-3 and 5-9 were less potent because the side chain at position 5 was too short to be accommodated by the hydrophobic subsite of $14 \alpha$ demethylase enzyme. Docking studies were performed to 
Table 1. Anti-candida and cytotoxic activities of 2,5-dimercapto-1,3,4-thiadiazole derivatives.

\begin{tabular}{ccc}
\hline Compound number & Candida albicans $\mathbf{~ C ~}_{\mathbf{5 0}}(\boldsymbol{\mu g} \mathbf{g} \mathbf{m l})$ & Cytotoxicity $_{(\% \text { inhibition at } \mathbf{5 0} \mathbf{\mu g} / \mathbf{m l})^{\mathbf{a}}}$ \\
\hline 1 & $>50$ & 58.52 \\
2 & $>50$ & 74.95 \\
3 & $>50$ & 70.32 \\
4 & 1.94 & 57.06 \\
5 & $>50$ & 7.29 \\
6 & $>50$ & 5.65 \\
7 & $>50$ & 4.54 \\
8 & $>50$ & 54.88 \\
9 & $>50$ & 59.61 \\
10 & 19.10 & 3.75 \\
Ellipticine $\left(\mathrm{IC} \mathrm{C}_{50}, \mu \mathrm{g} / \mathrm{ml}\right)$ & - & 1.490 \\
Amphotericin B & 0.045 & - \\
\hline
\end{tabular}

${ }^{a}$ The compounds were considered cytotoxic when percentage inhibition was $50 \%$ or greater at the concentration of $20 \mu \mathrm{g} / \mathrm{ml}$.

Table 2. The calculated docking energies and calculated $\mathrm{Ki}$ of the synthesized compounds.

\begin{tabular}{ccc}
\hline Compound number & $\Delta \mathbf{G}_{\text {dock }}(\mathrm{Kcal} / \mathrm{mol})$ & Calculated Ki \\
\hline 1 & -8.75 & $1.59 \times 10^{-6}$ \\
2 & -9.22 & $1.04 \times 10^{-6}$ \\
3 & -9.17 & $1.87 \times 10^{-6}$ \\
4 & -11.36 & $3.7 \times 10^{-7}$ \\
5 & -8.39 & $7.19 \times 10^{-7}$ \\
6 & -9.52 & $7.62 \times 10^{-7}$ \\
7 & -9.02 & $2.88 \times 10^{-6}$ \\
8 & -9.42 & $4.49 \times 10^{-7}$ \\
9 & -9.17 & $1.35 \times 10^{-6}$ \\
10 & -10.50 & $1.47 \times 10^{-7}$ \\
Voriconazole & -9.58 & $5.01 \times 10^{-6}$ \\
\hline
\end{tabular}

explained anti-candida activities.

The title compounds were also investigated for their cytotoxic activities. Ellipticine was used as the reference drug. As shown in Table 1, compounds 1 to 4,8 and 9 showed in vitro cytotoxicity activities against Vero cells (African green monkey kidney) at a concentration of 50 $\mu \mathrm{g} / \mathrm{ml}$. These results implied that their thiadiazole moiety was appropriate for binding firmly to the heme molecule of $14 \alpha$-demethylase enzyme. In contrast, the noncytotoxicity of compounds 5-7 and 10 may be due to the inappropriate location and orientation of the thiadiazole moiety, resulting in an inability to interact with the heme molecule.

\section{The mode of action of compounds 4 and 10 with the active site of $14 \alpha$-demethylase enzyme (CYP51)}

A docking study on the inhibitor/CYP51 interaction was performed to investigate the potential binding modes of compounds 4 and 10 . The docking simulation was carried out using the AutoDock 3.0 program using the X-ray crystal structure of cytochrome P450 14 $\alpha$-demethylase (PDB, 2CIB) as the target enzyme. This study was very useful in deriving guidelines for the design of new inhibitors in this 2,5-dimercapto-1,3,4-thiadiazole series. The 100 independent docking runs which were carried out for each ligand generally converged to a small number of different positions ("cluster" of results differing by less than $2.0 \AA$ root mean square deviation (rmsd). The binding site for CYP51 inhibitors is located at residues Phe22, Tyr76, Met79, Phe83, Phe255, Ala256, His259, Leu321, Ile322, Ile323, His430, Met433, Val434, Val435 and the heme. As shown in Table 2, the calculated docking energy $\left(\Delta G_{\text {dock }}\right)$ of compounds 4 and 10 was $-11.36 \mathrm{Kcal} / \mathrm{mol}$ and $-10.50 \mathrm{Kcal} / \mathrm{mol}$ and the calculated $\mathrm{Ki}$ of compounds 4 and 10 was $3.7 \times 10^{-7}$ and $1.47 \times 10^{-7}$, respectively which means that both 


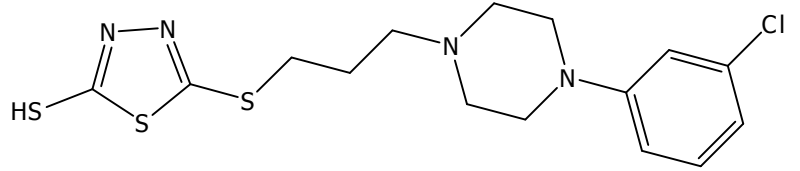

Compound 4

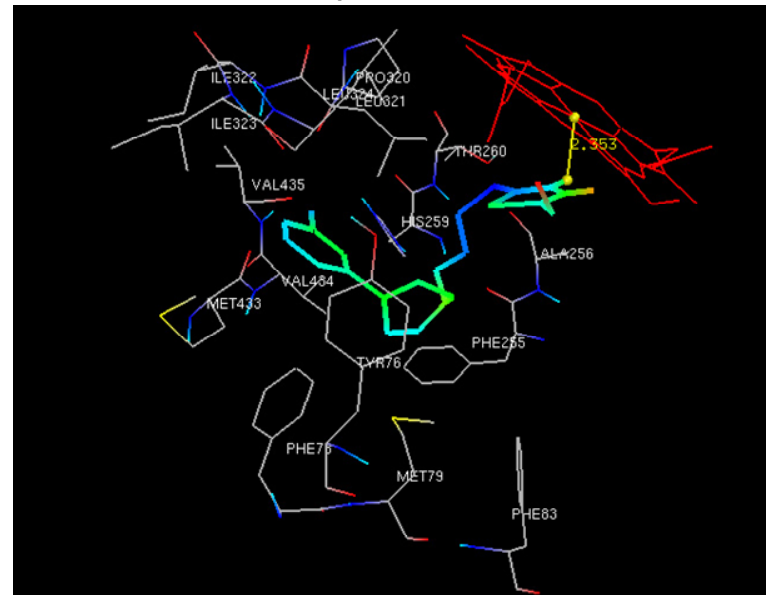

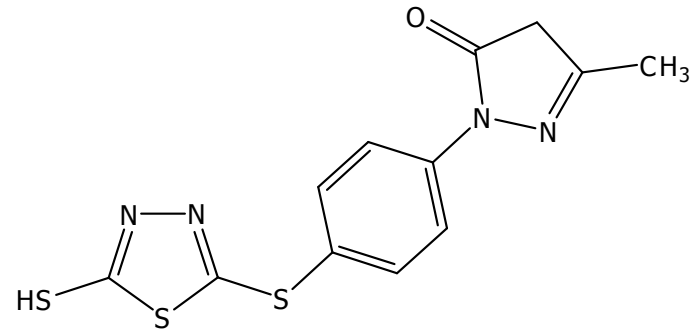

Compound 10

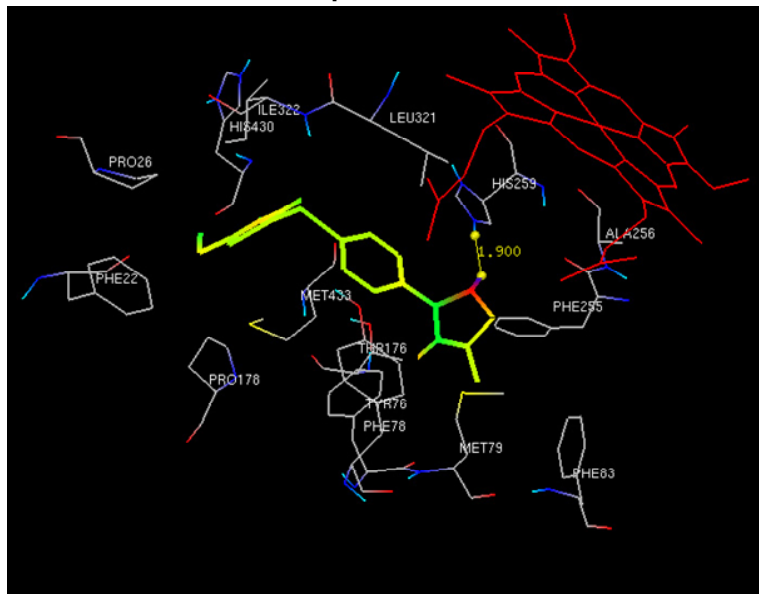

Figure 1. The mode of action of compounds 4 and 10 with the active site of $14 \alpha$ - demethylase enzyme.

compounds bound tightly to the CYP51 compared to voriconazole $\left(\Delta G_{\text {dock }}=-9.58 \mathrm{Kcal} / \mathrm{mol}, \mathrm{Ki}=5.01 \times 10^{-6}\right)$.

The mode of action of compound 4 with the active site CYP51 is shown in Figure 1. The nitrogen atom on the thiadiazole ring of molecule 4 forms coordination binding with the iron atom of heme. The lipophilic propyl spacer interacted with the narrow hydrophobic cleft of CYP51 (Phe255, Ala256, Thr260 and backbone of His259). The piperazine ring interacted with hydrophobic residues (Tyr76, Phe255). The chlorophenyl ring was inserted into the hydrophobic pocket (residues Tyr76, Val434, Val435, His259) of the enzyme. The binding interaction of compound 4 may be the cause of the serious side effects which can occur with other azole antifungals due to coordination binding with the iron atom of heme.

The carbonyl group on the pyrazole ring of compound 10 forms a hydrogen bond with the protonated nitrogen of His259. The methyl substituted pyrazole ring also has a hydrophobic interaction with the hydrophilic residues (Tyr76, Phe78, Thr176, Phe255). The phenyl spacer has a hydrophobic interaction with the residues Tyr76, Phe78, Thr176 and Met433. The SH group on the thiadiazole ring forms hydrogen bonds with the residues Phe22 and His430. Because the affinity of compound 10 for CYP51 was mainly attributed to the non-bonding interaction with the $14 \alpha$-demethylase enzyme, the studies presented here afford an opportunity to develop novel antifungal agents that specifically interact with the residues at the active site and avoid the serious toxicity which arises from coordination binding with the heme of mammalian P450s.

\section{Prediction of cytotoxic and non-cytotoxic activities of 2,5-dimercapto-1,3,4-thiadiazole derivatives}

To predict the cytotoxic and non-cytotoxic activities of 2,5-dimercapto-1,3,4-thiadiazole derivatives, the synthesized molecules were docked at the active site of $14 \alpha$-demethylase enzyme. As shown in Figure 2, the thiadiazole ring of compounds 1 to 4,8 and 9 showed a strong interaction with heme molecules. These interactions play a key role in determining the cytotoxic activities of 2,5-dimercapto-1,3,4-thiadiazole derivatives. As shown in Figure 3, no interactions were found between the thiadiazole moiety of non-cytotoxic molecules and the heme. The thiadiazole moiety of compound 5 forms hydrogen bond interactions with the backbone of Ala256. The orientation of the thiadiazole moiety of compound 6 was in the opposite direction to the heme molecule. The large distance from heme and the orientation of the thiadiazole moiety of compounds 7 and 10 explained the non-cytotoxic activities of both compounds. These results demonstrated that, the cytotoxic activities of 2,5-dimercapto-1,3,4-thiadiazole derivatives can be explained on the basis of the interactions between the 

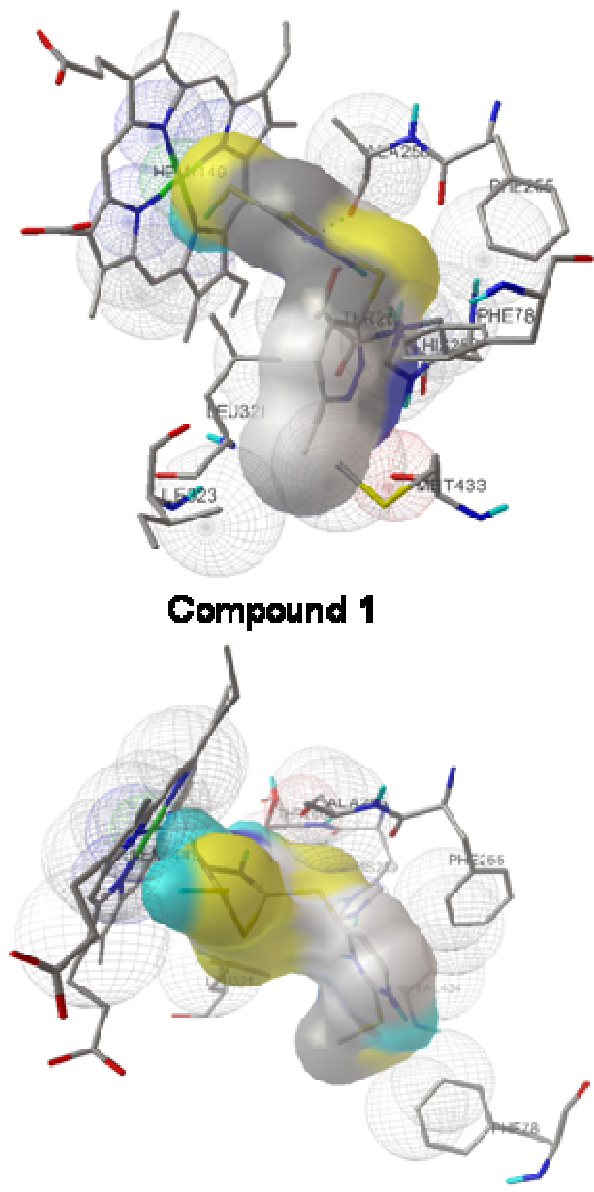

\section{Compound 3}

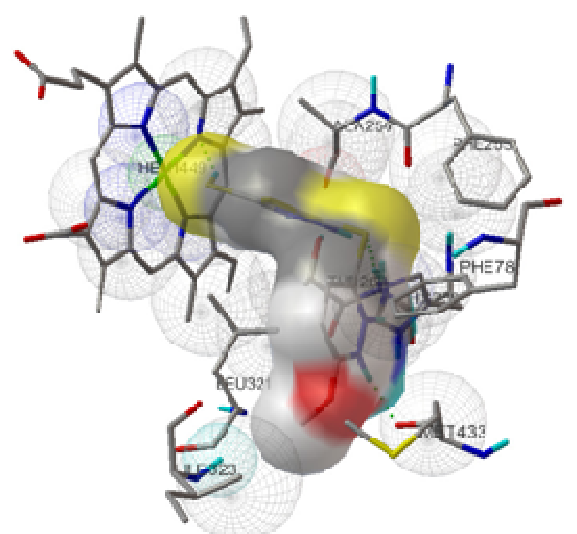

Compound 8

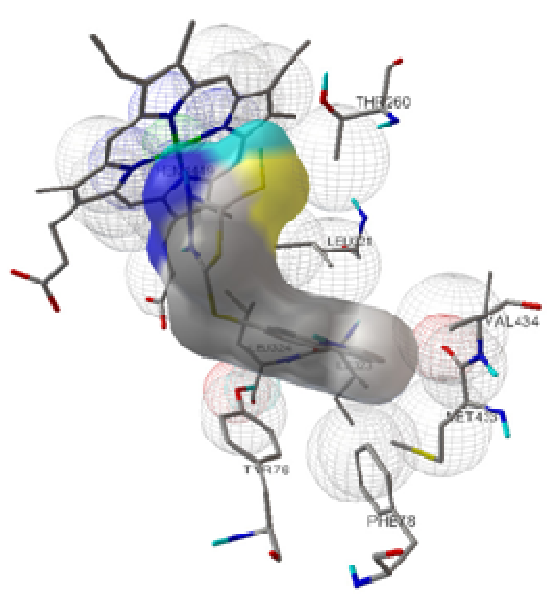

Compound 2

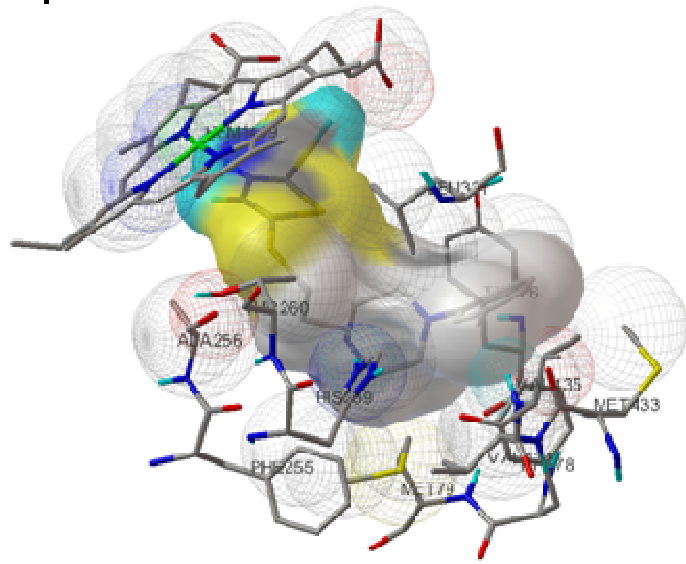

Compound 4

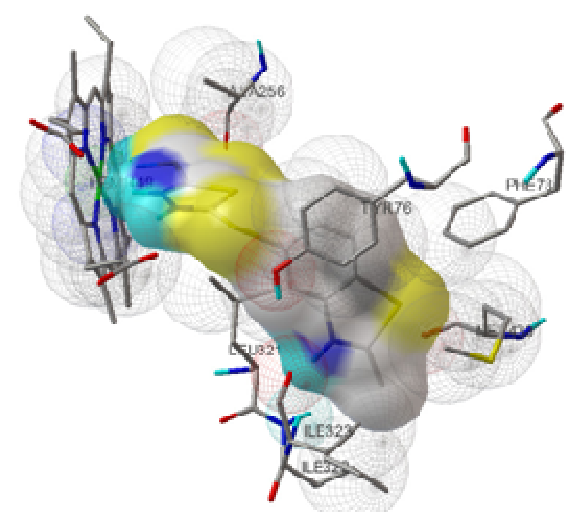

Compound 9

Figure 2. Docked conformations of cytotoxic compounds in the binding site of CYP51.

thiadiazole moiety of ligands and the heme molecule.

\section{Conclusion}

In conclusion, we have demonstrated the synthesis of a series of novel 2,5-dimercapto-1,3,4-thiadiazole derivatives. Some of the compounds were found to have good potency against $C$. albicans. The results obtained indicated that to increase the antifungal activity of these novel 2,5-dimercapto-1,3,4-thiadiazole derivatives, it is very helpful to introduce either 1-(3-chlorophenyl)-4-(3propyl)piperazine or 1-phenyl-3-methyl-2-pyrazolin-5-one as side chains to interact with the narrow hydrophobic cleft of CYP51 and adjust the physicochemical properties of the whole title molecules. The docking studies 

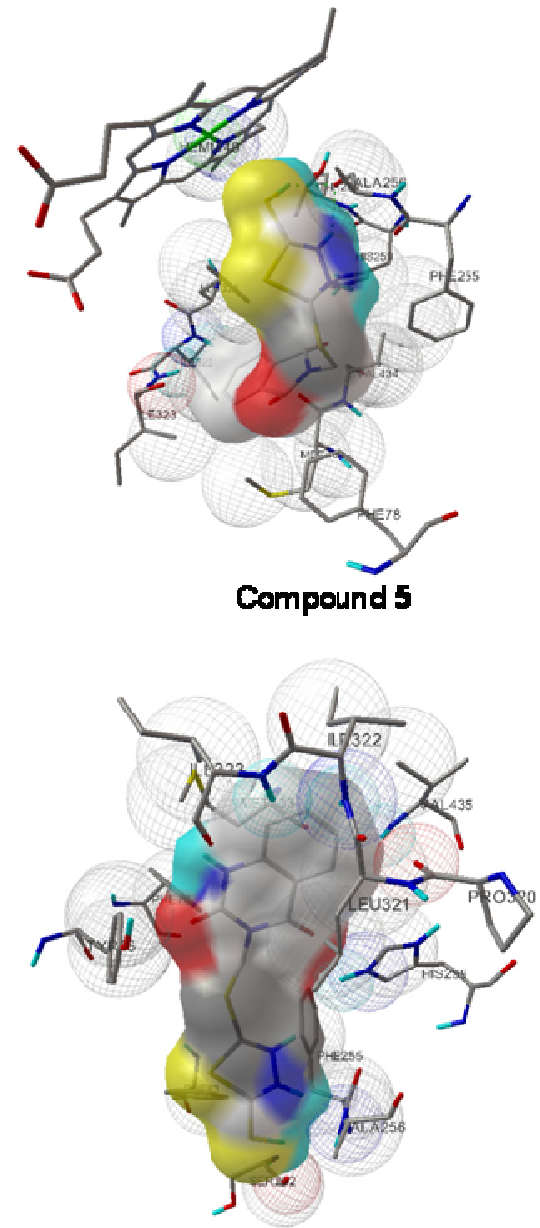

Compound 7

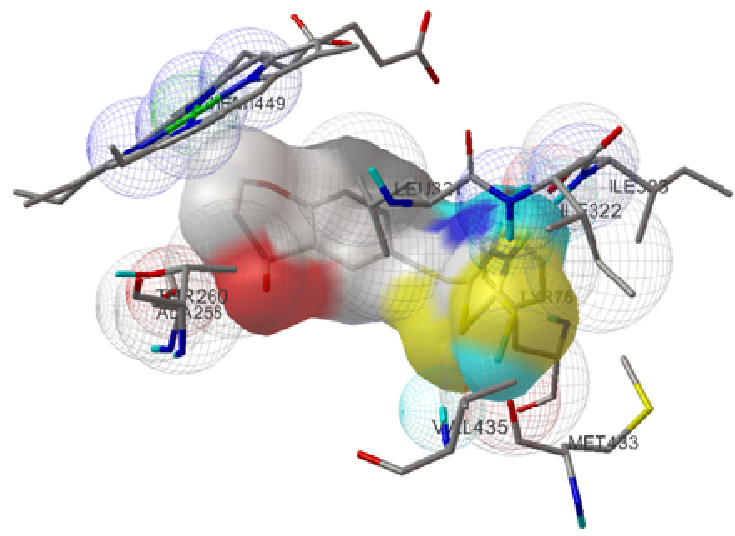

Compound 5

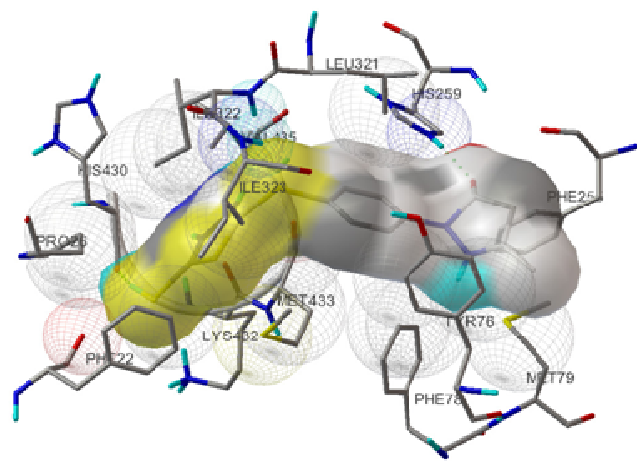

Compound 10

Figure 3. Docked conformations of non-cytotoxic compounds at the binding site of CYP51.

demonstrated that the thiadiazole-heme interactions may play a key role in determining the cytotoxicity of $2,5-$ dimercapto-1,3,4-thiadiazole derivatives. In a future study, 1-(2-(5-mercapto-1,3,4-thiadiazol-2-thio)phenyl)-3methyl-1H-pyrazol-5(4H)-one (compound 10 ) will be the lead compound to be developed as an azole antifungal with low toxicity.

\section{ACKNOWLEDGEMENTS}

The authors would like to thank the Thailand Research Fund (TRF) and the Commission on Higher Education $(\mathrm{CHE})$, Ministry of Education of Thailand for financial support (MRG 5080137).

\section{REFERENCES}

Abdel-Hamid MK, Abdel-Hafez AA, El-Koussi NA, Mahfouz NM, Innocenti A, Supuran CT (2007). Design, synthesis, and docking studies of new 1,3,4-thiadiazole-2-thione derivatives with carbonic anhydrase inhibitory activity. Bioorg. Med. Chem., 15: 6975-6984.
Andriole AT (2000). Current and future antifungal therapy: new targets for antifungal therapy. Int. J. Antimicrob. Agents., 16: 317-321.

Brien JO, Wilson I, Orton T, Pognan F (2000). Investigation of the alamar blue (resazurin) fluorescent dye for the assessment of mammalian cell cytotoxicity. Eur. J. Biochem., 267: 5421-5426.

Carvalho SA, da Silva EF, Santa-Rita RM, de Castro SL, Fraga CAM (2004). Synthesis and antitrypanosomal profile of new functionalized 1,3,4-thiadiazole-2-arylhydrazone derivatives, designed as nonmutagenic megazol analogues. Bioorg. Med. Chem., 14: 5967-5970.

Cartledge JD, Midgley J, Gazzard BG (1997). Itraconazole cyclodextrin solution: the role of in vitro susceptibility testing in predicting successful treatment of HIV-related fluconazole-resistant and fluconazole susceptible oral candidosis. AIDS, 11: 163-168.

Demirbas A, Sahin D, Demirbas N, Karaoglu SA (2009). Synthesis of some new 1,3,4-thiadiazol-2-ylmethyl-1,2,4-triazole derivatives and investigation of their antimicrobial activities. Eur. J. Med. Chem., 44: 2896-2903.

De Pauw BE, Picazo JJ (2008). Present situation in the treatment of invasive fungal infection. Int. J. Antimicrob. Agents. 32: S167-S171.

Dismukes WE (2000). Introduction to Antifungal Drugs. Clin. Infect. Dis., 30: 653-657.

Singh N (1997). Infections in solid-organ transplant recipients. Am. J. Infect. Control, 25: 409-417.

Dupont BF, Dromer F, Improvisi L (1996). The problem of azole resistance in Candida. J. Mycol. Med., 6(suppl II): 12-19.

Foroumadi A, Pournourmohammadi S, Soltani F, Asgharian-Rezaee M, Dabiri S, Kharazmi A, Shafiee A (2005). Synthesis and in vitro 
leishmanicidal activity of 2-(5-nitro-2-furyl) and 2-(5-nitro-2-thienyl)-5substituted-1,3,4-thiadiazoles. Bioorg. Med. Chem., 15: 1983-1985.

Hunt L, Jordan M, De Jesus M, Wurm FM (1999). GFP-expressing mammalian cells for fast, sensitive, noninvasive cell growth assessment in a kinetic mode. Biotechnol. Bioeng., 65: 201-205.

Ibrahim DA (2009). Synthesis and biological evaluation of 3,6disubstituted [1,2,4]triazole[3,4-b][1,3,4]thiadiazole derivatives as a novel class of potential anti-tumor agents. Eur. J. Med. Chem., 44: 2776-2781.

Jadhav VB, Kulkarni MV, Rasal VP, Biradar SS, Vinay MD (2008). Synthesis and anti-inflammatory evaluation of methylene bridged benzofuranyl imidazo[2,1-b][1,3,4]thiadiazoles. Eur. J. Med. Chem., 43: $1721-1729$.

Jalilian AR, Sttari S, Bineshmarvasti M, Daneshtalab M, Shafiee A (2003). Synthesis and in vitro antifungal and cytotoxicity evaluation of substituted 4,5-dihydronaphtho[1,2,3]thia(or selena)diazoles. II Farmaco, 58: 63-68.

Jatav V, Mishra P, Kashaw S, Stables JP (2008). CNS depressant and anticonvulsant activities of some novel 3-[5-substituted 1,3,4thiadiazole-2-yl]-2-styryl quinazoline-4(3H)-ones. Eur. J. Med. Chem., 43: $1945-1954$

Joseph-Horne T, Hollomon DW (1997). Molecular mechanism of azole resistance in fungi. FEMS Microbiol. Lett. 149: 141-149.

Kasımoğulları R, Bülbül M, Günhan H, Güleryüz H (2009). Effects of new 5-amino-1,3,4-thiadiazole-2-sulfonamide derivatives on human carbonic anhydrase isozymes. Bioorg. Med. Chem., 17: 3295-3301.

Katritzky AR, Slavov SH, Dobchev DA, Karelson M (2008). QSAR modeling of the antifungal activity against Candida albicans for a diverse set of organic compounds. Bioorg. Med. Chem. Lett., 16: 7055-7069.

Liu XH, Shi YX, Ma Y, Zhang CY, Dong WL, Pan L, Wang BL, Li BJ, Li ZM (2009). Synthesis, antifungal activities and 3D-QSAR study of $N$ (5-substituted-1,3,4-thiadiazol-2-yl)cyclopropanecarboxamides. Eur. J. Med. Chem., 44: 2782-2786.

Matysiak J, Opolski A (2006). Synthesis and antiproliferative activity of $\mathrm{N}$-substituted 2-amino-5-(2,4-dihydroxyphenyl)-1,3,4-thiadiazoles. Bioorg. Med. Chem., 14: 4483-4489.

Mirzaei J, Siavoshi F, Emami S, Safari F, Khoshayand MR, Shafiee A, Foroumadi A (2008). Synthesis and in vitro anti-Helicobacter pylori activity of $N$-[5-(5-nitro-2-heteroaryl)-1,3,4-thiadiazol-2yl]thiomorpholines and related compounds. Eur. J. Med. Chem., 43: 1575-1580.
Odds FC (1996). Epidermiological shifts in opportunistic and nosomial Candida infections: mycological aspects. Int. J. Antimicrob. Agents. 6: 141-144.

Sheehan DJ, Hitchcock CA, Sibbley CM (1999). Current and emerging azole antifungal agents. Clin. Microbiol. Rev. 12: 40-79.

Padmavathi V, Reddy GS, Padmaja A, Kondaiah P, Shazia A (2009). Synthesis, antimicrobial and cytotoxic activities of 1,3,4-oxadiazoles, 1,3,4-thiadiazoles and 1,2,4-triazoles. Eur. J. Med. Chem., 44: 21062112.

Pintilie O, Profire L, Sunel V, Popa M, Pui A (2007). Synthesis and antimicrobial activity of some new 1,3,4-thiadiazole and 1,2,4-triazole compounds having a $D, L$-methionine moiety. Molecul., 12: 103-113.

Podust LM, Von Kries JP, Eddine AN, Kim Y, Yermalitskaya LV, Kuehne R, Ouellet H, Warrier T, Altekoster M, Lee JS, Rademann J, Oschkinat H, Kaufmann SHE, Waterman MR (2007). Small molecule scaffolds for Cyp51 inhibitors identified by high throughput screening and defined by X-Ray crystallography. Antimicrob. Agents Chemother. 51: 3915-3923.

Rostom SAF, El-Ashmawy IM, Abd El Razik HA, Badr MH, Ashour HMA (2009). Design and synthesis of some thiazolyl and thiadiazolyl derivatives of antipyrine as potential non-acidic anti-inflammatory, analgesic and antimicrobial agents. Bioorg. Med. Chem., 17: 882895

Wei MX, Feng L, Li XQ, Zhou XZ, Shao ZH (2009). Synthesis of new chiral 2,5-disubstituted 1,3,4-thiadiazoles possessing $\gamma$-butenolide moiety and preliminary evaluation of in vitro anticancer activity. Eur. J. Med. Chem., 44: 3340-3344.

Yusuf M, Khan RA, Ahmed B (2008). Syntheses and anti-depressant activity of 5-amino-1, 3, 4-thiadiazole-2-thiol imines and thiobenzyl derivatives. Bioorg. Med. Chem., 17: 8029-8034.

Zheng KB, He J, Zhang J (2008). Synthesis and antitumor activity of $N^{1}$ acetylamino-(5-alkyl/aryl-1,3,4-thiadiazole-2-yl)-5-flurouracil. Chinese Chem. Lett., 19: 1281-1284.

Zhu J, Lu J, Zhou Y, Li Y, Cheng J, Zheng C (2006). Design, synthesis, and antifungal activities in vitro of novel tetrahydroisoquinoline compounds based on the structure of lanosterol $14 \alpha$-demethylase (CYP51) of fungi. Bioorg. Med. Chem. Lett., 16: 5285-5289. 